\title{
DIFFERENCES IN MILLENNIALS IN EMERGING MARKETS AND DEVELOPED COUNTRIES: THE CASE OF TURKEY AND THE UNITED STATES
}

\author{
Timothy $H$. Reisenwitz \\ Valdosta State Univeristy $\bullet$ Valdosta, GA \\ Ilke Kardes \\ Valdosta State Univeristy $\bullet$ Valdosta, GA \\ Asude Yasemin Zengin \\ Aksaray Univeristy • Aksaray, Turkey
}

\section{$\overline{\text { ABSTRACT }}$}

This study assesses the differences between Millennials (Generation Y) in advanced and emerging countries, using the United States and Turkey. The purpose is to give marketers more direction in better addressing the needs of Millennial consumers in advanced and emerging countries. Results showed that Millennials in the United States are more satisfied with online purchases, have higher brand loyalty, and were more risk-averse compared to the Millennials from Turkey. There are no significant differences between the two countries in terms of social media usage. This study enriches the existing literature and provides directions for further research.

Keywords: Gen Y, Millennials, Consumer, Emerging Markets, Developed Markets

\section{INTRODUCTION}

Generational cohorts share cultural, political, and economic experiences as well as have similar outlooks and values (Kotler \& Keller, 2006). Today, Millennials have been the main driver of markets both for emerging markets (EMs) and advanced economies due to their considerable representation in the workforce and their high propensities of spending. Millennial studies mainly stressed the characteristics of social media usage patterns. They typically focused on the high socioeconomic status consumers in advanced economies with a developed infrastructure of IT (Bolton et al., 2013). On the other hand, the population of the EMs accounts for more and more of the world's population day by day. As of October 2019, more than 6.56 billion of the world's population lives in EMs, and they account for almost 85 percent of the world's total population ("IMF", 2019). Thus, it is of importance to understand Generation Y's (Millennials') consumer behavior and characteristics in emerging markets to execute proper marketing activities in EMs. 
Marketers must adjust their marketing strategies to the dynamic needs of Millennial consumers, as Millennials continue to develop their careers and their disposable income increases. It is crucial for companies to get Millennials satisfied and loyal to their brands so that they can achieve a sustainable competitive advantage in the global marketplace. However, firms should treat Millennial consumers of advanced economies and EMs differently. They need to execute country-specific marketing/marketing communications strategies mainly because of the differences in economic and cultural atmospheres in developed and emerging countries.

\section{GENERATIONAL COHORTS}

Generational cohort theory is a theory of social history that "describes and elaborates on differences and changes in generational and public attitudes over time" (van der Walt et al., 2016, p. 53). A generational cohort consists of individuals who have shared the same external environment and events, which is thought to influence their behavior and thinking. The current generational cohorts in the United States consist of Matures or Traditionalists, Baby Boomers, Generation X, Generation Y, and most recently, Generation Z.

Although there is much consensus on the birth years for Matures (prior to 1946) and Baby Boomers (1946-64), there are variations for the birth years of Generation X, Generation Y, and Generation Z. There is currently little consensus of when Generation $Y$ ends, and Generation $Z$ begins. Much of the literature does not provide citations for the dates that were used to define these generational cohorts. Therefore, the long-standing, reputable research organization, the Pew Research Center, was chosen as the source for defining Gen Y by birth years. For purposes of this study, Generation Y is defined as those born during the years 1981-1996 (Dimock, 2019).

The term, Generation Y, was first coined in 1993 by Advertising Age as the last generation to be born entirely in the twentieth century (Reed, 2007). Generation $\mathrm{Y}$ is also known as Echo Boomers, the Millennium Generation, Millenniums or Millennials, Generation We, Connect 24/7, Leave No One Behind (Wiedmer, 2015), Generation Next (Durkin, 2008), Internet Generation (Wiedmer, 2015) or Net Generation (Tyler, 2008), and Generation Why? (Reed, 2007). There are about 60 million consumers in this group, over three times the size of their predecessors, Generation X (Montana \& Petit, 2008). 


\section{PURPOSE OF THE STUDY}

The purpose of this study is to evaluate the differences between Millennials in advanced and emerging countries, using the United States and Turkey, and based upon Hofstede's cultural dimensions. The aim is to give marketers more direction in better addressing the needs of Millennial consumers in advanced and emerging countries. Internet shopping satisfaction, social media usage, brand loyalty, and risk aversion are the examined variables in this study. Although there are a plethora of consumer variables that could be examined, the variables chosen are salient variables for youthful consumers (Internet shopping satisfaction, social media usage) and important variables in the purchase decision process (brand loyalty, risk aversion). These variables are discussed in the literature review that follows and are measured using established scales.

\section{LITERATURE REVIEW}

\section{Hofstede's Cultural Dimensions}

Culture plays an important role in shaping attitudes, perceptions, and behaviors. In international marketing literature, many scholars attempt to explain differences among countries based on culture. The impact of culture is investigated in a variety of contexts including online customer experience (Shobeiri et al., 2018), online product reviews (Wang et al., 2019), global Internet use (Gong et al., 2007), online shopping behavior (Stafford et al., 2004), perceived risk of online shopping (Ko et al., 2004), and the usage of social networks (Pookulangara \& Koesler, 2011).

One of the popular theoretical foundations to be used in culture-related studies is Hofstede's cultural dimensions. There are six dimensions including individualism/ collectivism, masculinity/femininity, power distance, uncertainty avoidance, longterm versus short-term orientation, and indulgence/restraint (Hofstede et al., 2010). Individualism/collectivism and uncertainty avoidance are the major focus of this study. The reason why only those dimensions are considered in this study is explained in the section of hypothesis development.

The original cultural framework by Hofstede was based on a cross-cultural study among employees of IBM Corporation and included four dimensions such as power distance, uncertainty avoidance, individualism/collectivism, and masculinity/feminity. Later, Hofstede added the fifth dimension as long-term versus short-term orientation in the framework (Hofstede \& McCrae, 2004). Finally, in the 2000s, the sixth dimension, indulgence/restraint, was included in the cultural dimensions (Hofstede, 2011). 
Power distance is related to the level of the inequality in a society. It explains how easy it is to reach the authorities, express opinions freely, and distribute rights evenly (Hofstede, 2011).

Indidividualism/collectivism is the degree of the ties between individuals. In collectivistic cultures, people develop strong group memberships. Personal decisions might be sacrified in favor of group conformity. In individualistic countries, "I"consciousness replaces "We"-consciousness. Personal opinions are expected (Hofstede, 2011).

Masculinity/femininity refers to whether competitive versus caring values dominate in a society. Ambition, competition, success-orientation, and being strong are typical values of a masculine culture. On the other hand, sympathy for the weak, caring values, and balance between work and family are more important in feminine cultures (Hofstede, 2011).

Uncertainty avoidance indicates the tolerance for uncertainties. In a society with high uncertainty avoidance, people experience high stress and anxiety in ambiguous situations. One might expect that such people may avoid taking risks to eliminate discomfort of an uncertain situation. Societies with low uncertainty avoidance tolerate chaos or unusual situations and people (Hofstede, 2011). One might expect that such societies may adapt changes in the environment faster, be open to innovations more, and establish new businesses with less hesitation.

Long-term versus short-term orientation explains whether the society leans towards future rewards versus tradition (Hollebeek, 2018; Hofstede, 2011). Individuals from cultures with long-term orientation values put more importance on long-term strategies and objectives (Khambata \& Liu, 2005).

Indulgence/restraint defines whether individuals allow themselves to show their desires and enjoy life versus whether their lives are shaped by strict social norms. Freedom of speech, enjoying leisure time, and expressing positive emotions are typical characteristics of an indulgent culture. On the other hand, a tendency towards being pessimistic and feeling helpless as well as a focus on work life rather than leisure are observed in restrained cultures (Hofstede, 2011).

Turkish and American cultures are considerably different, as seen in Table 1. According to Hofstede's country comparison at https://www.hofstede-insights. com/country-comparison/turkey,the-usa/, Turkey exhibits high on power distance and uncertainty avoidance, low on individualism and masculinity, as well as moderate long-term orientation and indulgence. On the other hand, the score of United States is high on individualisim, masculinity, and indulgence and low on power distance, uncertainty avoidance, and long-term orientation. 


\section{Table 1}

\section{Hofstede's Cultural Dimension Scores in \\ Turkey vs. United States (as of 2020)}

\begin{tabular}{lcccccc}
\hline & Power & Collectivism/ & & Uncertainty & Long Term \\
Distance & Individualism & Masculinity & Avoidance & Orientation & Indulgence \\
Turkey & 66 & 37 & 45 & 85 & 46 & 49 \\
United States & 40 & 91 & 62 & 46 & 26 & 68 \\
\hline
\end{tabular}

Source: https://www.hofstede-insights.com/product/compare-countries/

\section{Millennials (Generation $Y$ ) in the United States and in Turkey Satisfaction with online shopping}

The United States started to use the Internet in the early 1980s, and today Internet penetration rate is about 87 percent ("We Are Social," 2020). Thus, the Millennial grew up in a digital world, is technically literate, and has mastered the technology (Pelet \& Lecat, 2014). The Internet is a part of the daily routines and practices of Millennials (Issa \& Isaias, 2016). Thanks to technological improvement policies, Turkey started using the Internet in 1993. As of January 2020, the Internet penetration rate is about 54 percent ("We Are Social," 2020).

Since the US Millennials met and started to use the Internet almost a decade earlier than their peers in Turkey, Millennials in the US grew up with a more mature Internet infrastructure than their peers in Turkey. Several studies state the positive impact of habit on online shopping satisfaction and repurchase behavior (Pappas et al., 2014; Venkatesh et al., 2003).

Social interaction is an important factor that determines the choice of the retail shopping format. For some consumers, shopping is an experience beyond buying products and includes socialization through in-person discussions, such as consultations with salespersons or inconsequential conversations with other customers. Therefore, individuals who seek the intimacy of human contact during shopping tend to shop at brick-and-mortar retailers (Christodoulides \& Michaelidou, 2010). On the other hand, online shopping may be less satisfying for those consumers due to the lack of social interaction. From a culture-based viewpoint, collectivistic cultures put importance on group-based values and relationships (Soares et al., 2007). These priorities in a collectivistic culture may decrease satisfaction with online shopping because the online environment limits the physical interaction between individuals. According to a recent study, more collectivist values lead to less frequent e-purchase behavior, and lower intention to spend online (e.g., Korzeniowska, 
2015). Turkish cultural values are more collectivist than that of the United States. Therefore, the collectivistic nature of Turkish culture influences consumer attitude towards online shopping in Turkey. For instance, 35 percent of Internet users in Turkey and 69 percent of Americans shopped online in 2018 (Optinmonster, 2020). Based on this discussion, the following hypothesis is proposed:

\section{$H_{1}$ : Millennials in the US have higher overall satisfaction shopping with the Internet than Millennials in Turkey.}

\section{Social Media Usage}

Rising government investment in technology enhances Internet penetration rates and social media usage rates in emerging markets. The Turkish government's expenditure on IT was 913 million Turkish Lira (TL) in 2002. It reached TL 5,067 billion in 2018 (“T.C. Kalkınma Bakanlığ 1 ," 2018). As of 2019, the top five social networks are Youtube, Instagram, Whatsapp, Facebook, and Twitter based on the penetration rate ("Statista," 2020a).

Onurlubaş and Öztürk (2018) examined the effects of social media marketing strategies on Instagram on Millennials in Turkey. Research results suggest that almost all the respondents use Instagram every day, most of them one to two hours daily on average, and more than half of them comment on the contents posted on Instagram. The respondents shop mainly for clothing and cosmetics products. Effective Instagram strategies include the use of visual images, having a high number of consumer likes and followers, as well as celebrity usage.

Arslan and Baycan (2018) investigated the effect of social media on the purchasing behavior of Millennials in Turkey. The results reveal that media sharing sites, online communities, and social networks are the top platforms that influence purchasing behavior.

Millennials in the United States are well-versed in their use of the Internet and social media. The Pew Research Center reports that 92 percent of Millennials own a smartphone, 53 percent own a tablet, 84 percent use Facebook, and 86 percent use social media (Vogels, 2019). The percentage of Millennials who use social media has remained unchanged since 2012. As of 2019, the top five social networks apps are Facebook, Instagram, Facebook Messenger, Twitter, and Pinterest based on the number of monthly users ("Statista," 2020b). Furthermore, Millennials have influenced the development of social media via their employment in technology and social media companies (Bauman et al., 2019). About 73 percent said that the Internet has been good for society. 
Studies show that social media usage behavior varies based upon whether a country is characterized by individualistic or collectivistic cultural values (e.g., Kim et al., 2011; Alhabash et al., 2012; Fong \& Burton, 2008; Bolton et al., 2013). As seen in Table 1, Turkish cultural values encourage collectivist behaviors in contrast to the American individualistic cultural patterns. Due to collectivistic values, Turkish people tend to prioritize face-to-face communication in brick-andmortar environments although they enjoy social media communication. Based on the previous discussion, the following hypothesis is proposed:

\section{$\mathrm{H}_{2}$ : Millennials in the US have higher social media usage than Millennials in Turkey.}

\section{Brand Loyalty}

Recent studies imply that the Millennial in the United States has less brand loyalty. Nagy (2017) states that Millennials tend to be less brand loyal than previous generations and are resistant toward marketing and advertising. Kusek (2016) observed that cultural shifts in the United States have caused the demise of brand loyalty. Major changes in marriage, religion, politics, and corporate America have shaped a theme that change is good and it should not be feared or avoided, i.e., “'new' is better than 'known'” (Kusek, 2016, p. 3).

Similar to the US Millennial consumers, Turkish Millennial consumers' brand perception and brand satisfaction-related values are found to be lower than Generation X (Kahraman \& Dağl1, 2019). Millennial consumers of Turkey put great emphasis on the strong brand image (Coşkun, 2019) and emotional bonds as brand love (Kocakuş, 2019). Price and the accessibility of the product at the pre-purchase stage are important determinants for brand loyalty or switching behavior. Also, Millennials in Turkey reconsider their purchasing decision if there is a price increase (Coşkun, 2019). Moreover, Turkey's Millennials are ready to switch brands due to ecological reasons (Zengin \& Kumcu, 2018). As a result, it can be concluded that Millennial consumers of Turkey may not be keen on being brand loyal.

As discussed earlier, Millennials in both countries, the United States and Turkey, are less loyal to brands compared to the previous generations. Uncertainty avoidance of Hofstede's cultural dimensions may help to compare Millennials in the US and Turkey in terms of brand loyalty.

As noted in Table 1, the US has lower uncertainty avoidance compared to Turkey. Individuals from cultures with low uncertainty avoidance, such as the US, are more comfortable with uncertainties and open to changes. Experimenting with 
new brands and taking risks might be observed in such societies. On the other hand, cultures with high uncertainty avoidance, such as Turkey, tend to maintain the current situation because individuals are less risk takers. They might be more open to loyalty, tradition, and the environment that decreases unpredictability (Ndubisi et al., 2012). Previous studies show that brand attachment reduces perceived risk in shopping behavior and increases brand trust. On the other hand, perceived risk decreases consumers' willingness to try new brands/products (Aboulnasr \& Tran, 2020). Therefore, consumers stay loyal to their brands. According to some previous studies, consumers from individualistic cultures do not overlook quality defects (Donthu \& Yoo, 1998; Yoo, 2009) or inconvenient brand communications. However, consumers of collectivist cultures are more inclined to tolerate some failures in order to maintain the ongoing brand relationship (Yoo, 2009). Based on this discussion, the following hypothesis is proposed:

\section{$\mathrm{H}_{3}$ : Millennials in the United States are less loyal to brands than Millennials in Turkey.}

\section{Risk Aversion}

The preponderance of the literature concludes that Millennials in the United States are risk-averse. Moskowitz (2019) states that Millennials are the "most risk-averse generation since The Great Depression" (p. 1). A study by the Brookings Institution revealed that 52 percent of Millennials have a majority of their money in cash compared to an average of 23 percent for other generations (Moskowitz, 2019). Similarly, another study revealed that 28 percent of Millennials labelled themselves as risk takers versus 40 percent of Gen X and 43 percent of Baby Boomers (Chudgar, 2013). Millennials are risk-averse due to their continual state of safety and security, if viewed from the perspective of Maslow's Hierarchy of Needs model (Harrington, 2015).

In contrast, Millennials in Turkey grew up with liberalization policies beginning in the early 1980s. Political, economic, and cultural changes and developments in the country shaped Millennials in Turkey in terms of characteristics and socioeconomic behavior. Millennials in Turkey did not experience product scarcity, as it was the case for the generation that grew up before 1980. Thus, Millennials tend to consume anything rapidly (Göksel \& Güneş, 2017).

There is a change regarding the risk-taking behavior from earlier generations to Millennials in both countries. While Millennials have fewer risk takers compared to the previous generations in the United States, risk-taking behavior increased in Turkey. To compare Millennials between the two countries, Hofstede's cultural dimensions are utilized. 
Two of Hofstede's six cultural dimensions, uncertainty avoidance and longterm orientation, are evaluated as being related to risk aversion (Khambata \& Liu, 2005). The intermediate score of 46 for long-term orientation in Turkey is not enough to determine a characteristic for the country, according to the Hofstede's country comparison at https://www.hofstede-insights.com/country-comparison/turkey,the-usa/. Thus, to make a cross-cultural comparison between two countries about risk aversion, uncertainty avoidance is considered as a theoretical base.

According to the uncertainty avoidance dimension of Hofstede Insights (2020) in Table 1, Turkey scores 85 and is identified as a high uncertainty avoidance country. On the other hand, the United States scores 46, which is below average and relatively lower than Turkey's score. It means that Americans are relatively less reluctant for taking risks and more tolerant to new ideas (Hofstede Insights, 2020). Additionally, research findings suggest that countries with low uncertainty avoidance are the ones that are more stable socially, economically, and politically (Khambata \& Liu, 2005). Hence, a comparison between Turkey and the US on risk aversion is possible relying on uncertainty avoidance. Based on this discussion, the following hypothesis is proposed:

$\mathrm{H}_{4}$ : Millennials in the United States are less risk-averse than Millennials in Turkey.

\section{RESEARCH METHODOLOGY}

\section{Sample and Data Preparation}

The target population of the study was Millennials in Turkey and the United States. A convenience sampling technique was used to select respondents for both the Turkish and US samples. This convenience sample was deemed appropriate because the purpose of the study was not to provide point estimates of the variables but to test the relationships among them (Calder et al., 1981). Respondents from Turkey were mainly the residents of Ankara and Aksaray cities. The respondents were volunteers and were not provided any incentives for their participation. Respondents from the United States were undergraduate students at a medium-sized university in the southeastern United States. They were also not provided with any incentives for their participation.

Based on the definition of Millennials by Pew Research (Dimock, 2019), people who were born between 1981 and 1996 living in the United States and in Turkey were administered a face-to-face questionnaire. The authors are bilingual. The questionnaire was translated from English to Turkish. Then, the Turkish version 
was back translated to evaluate differences in the two versions of the questionnaire. A total of 130 questionnaires in Turkey and 163 in the United States were distributed. Questionnaires were obtained from 101 respondents living in the United States and 111 living in Turkey. One case from the US sample and five cases from the Turkish sample were dropped due to a considerable amount of missing data. A total of 206 usable responses remained.

If the value of only one variable among associated variables that form a construct is missing, that value was imputed with means of peer variables of that construct. Therefore, missing values were imputed for two cases in the US sample for the construct of interaction in social media, one case in the US sample and one in the Turkish sample for the construct use of social media in shopping, one case in the US sample and five cases in the Turkish sample for the construct of brand loyalty, two cases in both the US and Turkish samples for the construct of satisfaction, and two cases in the Turkish sample. Table 2 shows the demographics of the sample.

Table 2

Sample Demographics

\begin{tabular}{lcc}
\hline Respondent Profile & \multicolumn{2}{c}{$\%$ of respondents } \\
& US & Turkey \\
\cline { 2 - 3 } Gender & & \\
Male & 46.9 & 41.1 \\
Female & 53.1 & 58.9 \\
\hline Education & & \\
GED & 6.0 & 0 \\
High School & 20.0 & 1.9 \\
Undergraduate & 54.0 & 62.0 \\
Graduate & 17.0 & 36.1 \\
Professional degree & 3.0 & 0 \\
\hline Occupation & & \\
Student & 51.0 & 13.1 \\
Homemaker/Not & 4.0 & 7.5 \\
Employed & & \\
Self-Employed & 4.0 & 16.8 \\
Educator & 1.0 & 2.8 \\
Professional & 38.0 & 53.3 \\
Other & 2.0 & 6.5 \\
\hline Marital & & \\
Married & 18 & 39.3 \\
Single & 68 & 60.7 \\
Living with another & 12 & 0 \\
Divorced & 2 & 0 \\
\hline
\end{tabular}


Table 2

\section{Sample Demographics (continued)}

\begin{tabular}{|c|c|c|}
\hline & US & Turkey \\
\hline \multicolumn{3}{|l|}{ Internet Use - Reason in \% } \\
\hline Stay in touch with friends and relatives & $88 \%$ & $82.1 \%$ \\
\hline Stay current with news and events & $82 \%$ & $91.5 \%$ \\
\hline Access the chat rooms & $16 \%$ & $9.4 \%$ \\
\hline Access discussions/newsgroups & $25 \%$ & $19.8 \%$ \\
\hline Shopping/gathering product information & $81 \%$ & $72.6 \%$ \\
\hline Entertainment & $92 \%$ & $47.2 \%$ \\
\hline Access health/medical information & $50 \%$ & $37.7 \%$ \\
\hline Check stocks and information & $24 \%$ & $13.2 \%$ \\
\hline Perform stock transactions & $9 \%$ & $4.7 \%$ \\
\hline Research specific topics (other than health) & $66 \%$ & $59.4 \%$ \\
\hline \multicolumn{3}{|l|}{ Internet Access - Device } \\
\hline My own computer (PC) & $51 \%$ & $21.3 \%$ \\
\hline By mobile phone & $47 \%$ & $75 \%$ \\
\hline My web TV & $0 \%$ & $0.9 \%$ \\
\hline A friend/relative's computer & $0 \%$ & $0 \%$ \\
\hline A computer at the library/community center & $0 \%$ & $2.8 \%$ \\
\hline A computer at work/school & $2 \%$ & $0 \%$ \\
\hline \multicolumn{3}{|l|}{ Internet Usage - Weekly average } \\
\hline 20 hours or more & $40 \%$ & $41.5 \%$ \\
\hline 10-19 hours & $34 \%$ & $21.7 \%$ \\
\hline 5-9 hours & $20 \%$ & $23.6 \%$ \\
\hline less than 5 hours & $6 \%$ & $13.2 \%$ \\
\hline \multicolumn{3}{|l|}{ Online Shopping - Frequency } \\
\hline Never & $3 \%$ & $0 \%$ \\
\hline Once-Twice a year & $19 \%$ & $25 \%$ \\
\hline Once a month & $35 \%$ & $39.8 \%$ \\
\hline A few times a month & $31 \%$ & $29.6 \%$ \\
\hline Once a week & $8 \%$ & $1.9 \%$ \\
\hline More than once a week & $4 \%$ & $3.7 \%$ \\
\hline
\end{tabular}


According to the frequency analysis, seen in Table 2, the top five reasons of being involved with the Internet are staying in touch with friends and relatives, following news and events, shopping or gathering product information, entertainment, and research specific topics (other than health). Both consumer groups access the Internet via either a personal computer or mobile phone, among others. Mobile phone usage is higher in Turkey than in the United States.

In terms of the frequency of Internet usage and its weekly consumption, 97 percent of both groups access the Internet daily. Among them, 40 percent of the American Millennials compared to around 42 percent of the Turkish Millennials spend 20 hours or more weekly on the Internet. In terms of shopping activities, 66 percent of the Millennials from the United States and around 69 percent of the ones from Turkey shop online at least once a month.

\section{Constructs and Measures}

The questionnaire includes three types of questions to measure demographics, characteristics in terms of Internet usage behavior, and online shopping. The demographics of the sample are presented in Table 2.

All scales are well-established and have been used in previous research. Satisfaction with Internet shopping was assessed using a four-item scale used by Rose et al. (2012), which is a modification of a scale developed by Khalifa and Liu (2007). Rose et al. (2012) provided evidence in support of the scale's convergent and discriminant validities. The social media usage scale was created by Rapp et al. (2013). Three of the ten statements that were context-specific, i.e., focused on a brand or store, were removed, with the remaining seven statements broadly covering social media usage. Brand loyalty was measured using the four-item scale developed and used by Lichtenstein et al. (1990) and Raju (1980). The risk aversion scale was measured by a modified four-item scale used by Donthu and Gilliland (1996). All items were measured on a seven-point Likert scale from $1=$ strongly disagree to $7=$ strongly agree, in which the rating, 4 , was for respondents who felt neutral.

The following section reports the results of independent samples t-tests, which tested the hypotheses of online shopping behavior. The reason for running a non-parametric test, such as an independent samples t-test, is that the constructs are not normally distributed according to the Kolmogorov-Smirnov test. In the absence of normality, non-parametric tests should be run (Coussement et al., 2016). All analyses were conducted via SPSS. 


\section{ANALYSIS AND RESULTS}

Reliability coefficients were computed for each of the scales. Coefficient alphas were reported for the US group and the Turkish group as well as the total sample. All alpha values were above the 0.70 value recommended by Nunnally (1978). Table 3 presents the reliability of the items.

\section{Table 3}

\section{Reliability Coefficients}

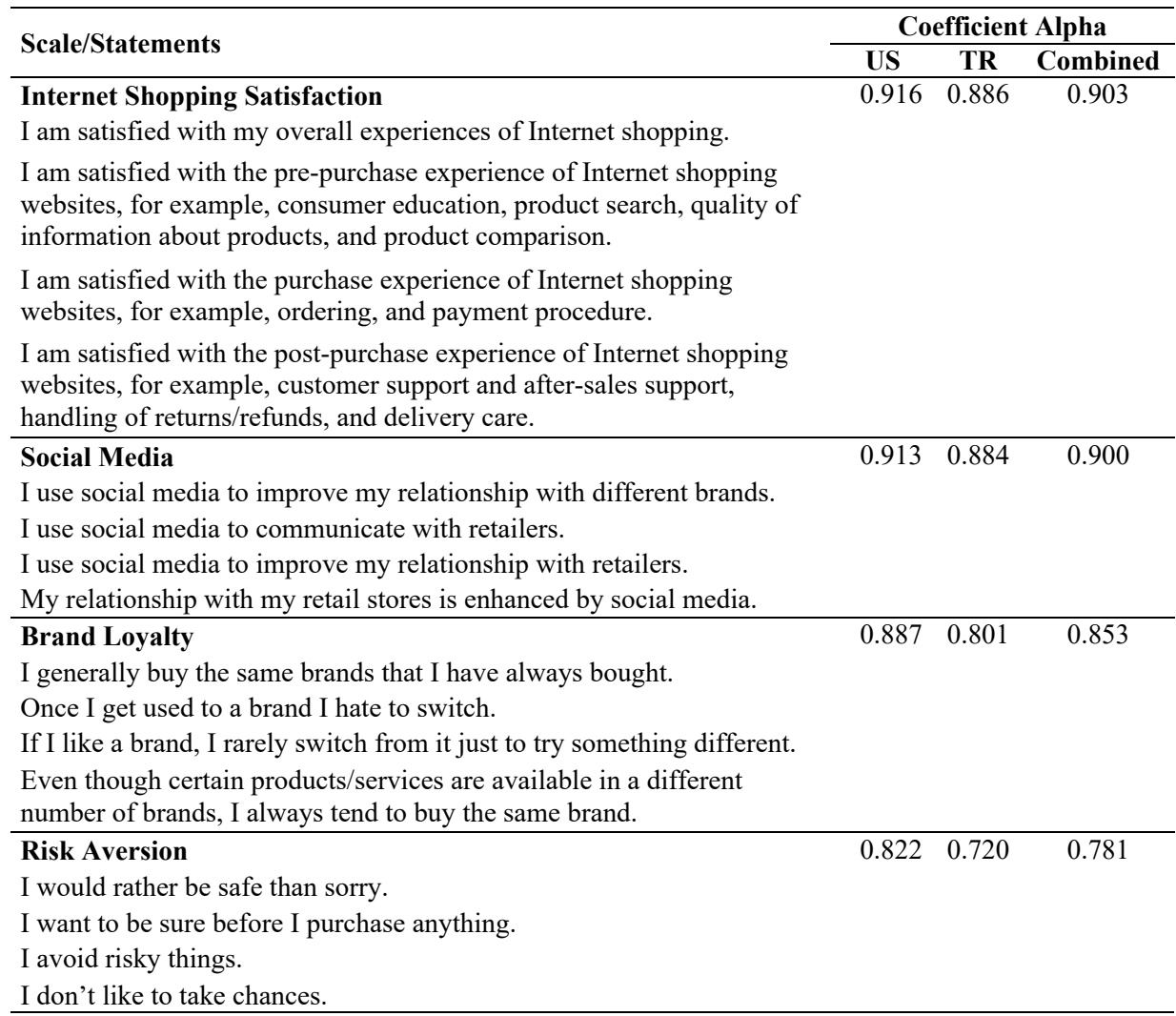

A principal component analysis (PCA) was run to identify whether the scale items build the expected constructs. The suitability of the scale items is determined by the Kaiser-Meyer-Olkin (KMO) Test and Bartlett's Test of Sphericity. The KMO Test checks the sample adequacy to conduct PCA. A high value of KMO is expected, and a value below 0.5 is not acceptable. The KMO value of the analysis is 0.807 , as seen in Table 4. Barlett's Test checks scale items correlation. A high correlation among variables implies that the variables are suitable for structure detection. A 
significance level $<.05$ indicates that PCA is useful within the data. The significance value of the analysis is 0.000 , as seen in Table 4 . The rotated component matrix, as seen in Table 4, is useful to form constructs based on the factor loadings of the variables. Loadings close to 1 indicate that the component (factor) strongly influences the variable and the highest loadings under a component constitute a construct. According to the results of the principal component analysis, there are five constructs as follows: Satisfaction with online purchase, interactions in social media, social media use in shopping, brand loyalty, and risk aversion.

\section{Table 4}

\section{Principal Component Analysis}

\begin{tabular}{|c|c|c|}
\hline \multicolumn{3}{|c|}{ KMO and Bartlett's Test } \\
\hline Kaiser-Meyer-Ol & ure of Sampling Adequacy & 0.807 \\
\hline $\begin{array}{l}\text { Bartlett's Test of } \\
\text { Sphericity }\end{array}$ & $\begin{array}{l}\text { Approx. Chi-Square } \\
\text { df } \\
\text { Sig. }\end{array}$ & $\begin{array}{r}1853.759 \\
120 \\
0.000\end{array}$ \\
\hline
\end{tabular}

\begin{tabular}{|c|c|c|c|c|c|}
\hline & \multicolumn{4}{|c|}{ Rotated Component Matrix ${ }^{a}$} & \multirow[b]{3}{*}{ Constructs } \\
\hline & \multicolumn{4}{|c|}{ Component } & \\
\hline & 1 & 2 & 3 & 4 & \\
\hline Sat1 & 0.895 & 0.127 & 0.106 & -0.029 & \multirow{4}{*}{ Satisfaction } \\
\hline Sat2 & 0.878 & 0.121 & 0.128 & 0.041 & \\
\hline Sat3 & 0.883 & 0.050 & -0.007 & -0.050 & \\
\hline Sat4 & 0.845 & 0.062 & 0.067 & 0.073 & \\
\hline SM1 & 0.055 & 0.820 & 0.213 & -0.086 & \multirow{4}{*}{ Social media use } \\
\hline SM2 & 0.124 & 0.883 & 0.032 & 0.131 & \\
\hline SM3 & 0.093 & 0.921 & 0.128 & 0.039 & \\
\hline SM4 & 0.089 & 0.862 & 0.067 & -0.041 & \\
\hline BL1 & 0.084 & 0.165 & 0.703 & 0.154 & \multirow{4}{*}{ Brand loyalty } \\
\hline BL2 & 0.006 & 0.058 & 0.872 & 0.113 & \\
\hline BL3 & 0.150 & 0.078 & 0.813 & 0.051 & \\
\hline BL4 & 0.042 & 0.114 & 0.860 & 0.139 & \\
\hline Risk1 & 0.115 & 0.017 & 0.147 & 0.775 & \multirow{4}{*}{ Risk aversion } \\
\hline Risk2 & 0.009 & 0.003 & 0.174 & 0.649 & \\
\hline Risk3 & -0.013 & -0.019 & 0.111 & 0.863 & \\
\hline Risk4 & -0.072 & 0.030 & -0.012 & 0.784 & \\
\hline
\end{tabular}

Extraction Method: Principal Component Analysis.

Rotation Method: Varimax with Kaiser Normalization.

a. Rotation converged in 5 iterations.

\section{Hypotheses Testing}

The independent samples t-test was conducted to determine whether there are significant mean differences between Millennials in the United States and in Turkey 
in terms of satisfaction with online purchase, interactions in social media, social media use in shopping, brand loyalty, and risk aversion. Table 5 presents the results.

\section{Table 5}

\section{Independent Samples T-test Analysis}

\begin{tabular}{|llllllllll|}
\hline Constructs & $\begin{array}{c}\text { df } \\
\text { (Equal } \\
\text { variances } \\
\text { assumed) }\end{array}$ & Country & $\mathrm{N}$ & Mean & Std. Dev. & $\begin{array}{l}\text { Error } \\
\text { Mean }\end{array}$ & t-value Sig. \\
& \multirow{2}{*}{ Satisfaction } & 206.00 & US & 100 & 5.42 & 1.27 & 0.13 & 0.13 & \\
& & Turkey & 108 & 4.89 & 1.28 & 0.12 & 0.12 & 0.003 \\
\hline Social & \multirow{2}{*}{206.00} & US & 100 & 2.79 & 1.56 & 0.16 & 0.16 & \\
Media & Turkey & 108 & 2.45 & 1.45 & 0.14 & 0.14 & 0.101 \\
\hline \multirow{2}{*}{ Loyalty } & \multirow{2}{*}{206.00} & US & 100 & 4.83 & 1.49 & 0.15 & 0.15 & \\
& \multirow{2}{*}{ Risk } & Turkey & 108 & 4.01 & 1.34 & 0.13 & 0.13 & 0.000 \\
\hline
\end{tabular}

As seen in Table 5, there are significant differences in satisfaction with internet purchase, brand loyalty, and risk aversion between Millennials from the United States and the ones from Turkey at $\mathrm{p}<0.01$. On the other hand, the difference in terms of social media (interaction and shopping) between the two groups is not statistically significant. Therefore, the second hypothesis $\left(\mathrm{H}_{2}\right.$ : Millennials in the US have higher social media usage than members of Millennials in Turkey.) is not supported.

The means of satisfaction, loyalty, and risk are higher, and statistically significant, in the US sample than they are in the Turkish sample. The interpretation of the analysis is that US Millennials are more satisfied with online purchases, have higher brand loyalty, and are more risk-averse compared to the Millennials from Turkey. Therefore, the results of the analysis support the first hypothesis $\left(\mathrm{H}_{1}\right.$ : Millennials in the US have higher overall satisfaction shopping with the Internet than Millennials in Turkey.). However, the third hypothesis (H3: Millennials in the United States are less loyal to brands than Millennials in Turkey.) and the fourth hypothesis (H4: Millennials in the United States are less risk-averse than members of Millennials in Turkey.) are not supported. Table 6 summarizes the hypotheses testing. 
Table 6

Summary of Hypotheses Testing

\begin{tabular}{|c|c|c|c|}
\hline Hypothesis & Significance & $\begin{array}{l}\text { Means of the } \\
\text { samples }\end{array}$ & $\begin{array}{l}\text { Supported }(\sqrt{ }) \text { vs. } \\
\text { Not supported }(-)\end{array}$ \\
\hline $\begin{array}{l}\text { H1: Millennials in the US have higher overall } \\
\text { satisfaction shopping with the Internet than } \\
\text { Millennials in Turkey. }\end{array}$ & 0.003 & $\begin{array}{l}\text { US: } 5.42 \\
\text { TR: } 4.89\end{array}$ & $\sqrt{ }$ \\
\hline $\begin{array}{l}\text { H2: Millennials in the US have higher social media } \\
\text { usage than Millennials in Turkey. }\end{array}$ & 0.101 & $\begin{array}{l}\text { US: } 2.79 \\
\text { TR: } 2.45\end{array}$ & - \\
\hline $\begin{array}{l}\text { H3: Millennials in the United States are less loyal to } \\
\text { brands than Millennials in Turkey. }\end{array}$ & 0.000 & $\begin{array}{l}\text { US: } 4.83 \\
\text { TR: } 4.01\end{array}$ & - \\
\hline $\begin{array}{l}\text { H4: Millennials in the United States are less risk- } \\
\text { averse than Millennials in Turkey. }\end{array}$ & 0.000 & $\begin{array}{l}\text { US: } 5.38 \\
\text { TR: } 4.68\end{array}$ & - \\
\hline
\end{tabular}

\section{MANAGERIAL IMPLICATIONS}

Millennials in the United States are more satisfied with online shopping than those in Turkey. The low satisfaction level in Turkey can be explained by the impact of collectivist values and habits of shopping. Online shopping is less favorable for consumers who seek social interactions (Christodoulides \& Michaelidou, 2010). Cultures with collectivist values prioritize relationships and group conformity (Soares et al., 2007). In terms of habits, Turkish Millennials met the Internet at a later time in their lives compared to their counterparts in the United States. They already had a shopping routine shaped by brick-and-mortar stores. A lack of habit with online shopping may decrease satisfaction because habit has a moderator effect on online shopping satisfaction and repurchase behavior (Pappas et al., 2014; Venkatesh et al., 2003). Satisfaction with online shopping can be increased with enhancing the cognitive and affective experience of the customer (Rose et al., 2012; Homburg et al., 2006). Factors related to website navigation, such as website design and visual elements, influence cognitive experience (Novak et al., 2000). Retailer credibility and positive word-of-mouth toward the online retailer may improve the affective experience (Bhattacharya et al., 2019).

Thus, marketers can be confident in taking advantage of US Millennials' satisfaction with online shopping by providing online shopping opportunities. Whereas, marketing toward Turkish Millennials should take a more traditional retailing approach with online shopping more focused toward the information search stage of the purchase decision process. 


\section{THEORETICAL IMPLICATIONS}

There are many studies about online shopping, social media usage, and comparing consumer behavior between emerging markets and developed countries. Nevertheless, there is little research about the behavior and attitude of Millennials. Thus, this study enriches the existing literature and provides directions for further research. Since particularly little is known about the differences in consumer behavior of Millennials in terms of Internet shopping satisfaction and social media use behavior, this study stands as a base for Millennial consumer behavior and cross-cultural differences. It can be a starting point for the examination of Internet shopping and social media usage in emerging markets and developed countries.

According to some studies related to culture, countries with higher individualism, like the United States, exhibit more brand-switching behavior, less brand loyalty, and less risk avoidance compared to collectivist cultures like Turkey (Rajamma et al., 2010; Lee \& Lim 2008; Liu et al., 2001). However, the results of the study suggest that Millennials in the United States are more brand loyal and risk-averse in comparison to Millennials in Turkey. A possible explanation might be found in socioeconomic factors, such as occupation, as well as political and economic conditions in the country (Pitta \& Gurău, 2012). According to a study by Pitta and Gurău (2012), brand loyalty in Millennial students is higher than it is in Millennial professionals. From a socioeconomic perspective, the amount of disposable income may play a role on the relationship between a brand and a consumer. Consumers in emerging markets, where the income level is lower, may search for branded products with discounted prices rather than establish brand loyalty (Morgeson III et al., 2015). Therefore, socioeconomic factors have to be considered in studies related to Millennials. Millennials exhibit more brand-switching behavior and price consciousness in emerging markets than in developed countries.

Regarding risk aversion, the results show that Turkish Millennials are more prone to risk taking than US Millennials. However, Hofstede's cultural dimensions suggest that individualistic cultures are more inclined to risk taking. The findings of this study may be best explained by the ongoing economic progress in Turkey. Particularly, the liberalization steps after 1983 resulted in growing GDP, employment and wealth. The Millennials, who were born in early phases of the liberalization, had the chance of growing up in a politically and economically more stable, safe, and plentiful country. They did not even face the scarcity of convenience goods or poverty as their parents experienced. They wanted to achieve more than their parents due to their difficult economic and political conditions. Hence, the improvements in 
social, economic and political conditions make Turkish Millennials more confident about the future and eager to take the risk to get better opportunities.

\section{LIMITATIONS AND FUTURE RESEARCH}

This cross-cultural study has some challenges. The main limitation of this research is the sample size. The sample size is not suitable enough to make generalizations regarding developed and emerging market consumers. It cannot also be treated as representative enough for the Millennial populations of the two countries.

Sample characteristics is another limitation. While the US sample is comprised of mostly students, the Turkish sample heavily consists of non-student consumers. Due to the fact that the sample characteristics of this study are not homogeneous enough in terms of life stages of the consumers, future research may use samples from EMs and developed countries that capture consumers from different educational, social, and economic backgrounds.

Another limitation of this research is only investigating the differences in consumer behavior of Millennials. Future research may focus on a comparison between Millennials (Gen Y) and Gen Z consumers.

The next limitation is the comparison between the United States and Turkey. More than two countries could be compared in future research. This may provide a basis for better understanding the differences between the Internet and/or social media usage, online buying, and post-purchase behavior of consumers of emerging markets and developed countries.

It should be noted that Millennials may not exhibit the cultural tendencies in the same way as reported by Hofstede. Furture research could be conducted to determine this possibility. If found, this could be an important contribution. Also, future research may cover the underlying reasons for the variance in Internet shopping behavior of consumers both in emerging economies and developed countries. In addition, future studies may focus on the effects of Internet buying satisfaction and social media marketing on brand loyalty and contrast international differences. Moreover, further research may investigate and compare the other aspects of postpurchase behavior as positive word-of-mouth or complaint behavior. 


\section{REFERENCES}

Aboulnasr, K. \& Tran, G.A. (2020). Is love really blind? The effect of emotional brand attachment on the perceived risk of really new products. Journal of Product \& Brand Management, 29(1), 81-96.

Alhabash, S., Hyojung, P., Kononova, A., Chian, Y. \& Wise, K. (2012). Exploring the motivation of Facebook use in Taiwan. Cyberpsychology, Behavior and Social Networking, 15(6), 304-311.

Arslan, I. K. \& Baycan, P. (2018). Tüketici satınalma davranışları üzerinde sosyal medyanın etkisi: Y kuşağı üzerine bir araştırma. İstanbul Ticaret Üniversitesi Sosyal Bilimler Dergisi, 33, 269-286.

Bauman, M. J., Velikova, N., Dodd, T. \& Blankenship, T. (2019). Generational differences in risk perception and situation uses of wine information sources. International Journal of Wine Business Research, 32(2), 247-265.

Bhattacharya, A., Srivastava, M. \& Verma, S. (2019). Customer experience in online shopping: A structural modeling approach. Journal of Global Marketing, 32(1), 3-16.

Bolton, R., N., Parasuraman, A., Hoefnagels, A., Migchels, N., Kabadayi, S., Gruber, T., Komarova Loureiro, Y. \& Solent, D. (2013). Understanding Generation Y and their use of social media: A review and research agenda. Journal of Service Management, 24(3), 245-267.

Calder, B. J., Phillips, L. W. \& Tybout, A. M. (1981). Designing research for application. Journal of Consumer Research, 8, 197-207.

Christodoulides, G. \& Michaelidou, N. (2010). Shopping motives as antecedents of e-satisfaction and e-loyalty. Journal of Marketing Management, 27(1-2), 181197.

Chudgar, S. (2013). Forget Gen Y: Baby Boomers are the Real Entrepreneurial Risk Takers, Inc. https://www.inc.com/sonya-chudgar/your-parents-may-be-betterentrepreneurs-than-you.html

Coşkun, M. (2019). Marka bağlılı̆̆ının tüketici satın alma davranışları üzerine etkisi: $\mathrm{X}$ ve Y kuşaklarının cinsiyete göre karşılaştırmalı analizi. International Journal of Academic Value Studies, 5(2), 271-286.

Coussement, K., Demoulin, N. \& Charry, K. (2016). Marketing Research with SAS Enterprise Guide. Routledge Publishing.

Dimock, M. (2019). Defining generations: Where Millennials end and Generation $\mathrm{Z}$ begins, Pew Research Center, January 17, https://www.pewresearch.org/facttank/2019/01/17/where-millennials-end-and-generation-z-begins/. 
Donthu, N. \& Gilliland, D. (1996). Observations: The infomercial shopper, Journal of Advertising Research, 36, 69-77.

Donthu, N. \& Yoo, B. (1998). Cultural influences on service quality expectations. Journal of Service Research, 1, 178-185.

Durkin, D. (2008). Youth movement. Communication World, 25, 23-26.

Fong, J. \& Burton, S. (2008). A cross-cultural comparison of electronic word-ofmouth and country-of-origin effects. Journal of Business Research, 61(3), 233242 .

Gong, W., Li, Z.G. \& Stump, R.L. (2007). Global internet use and access: cultural considerations. Asia Pacific Journal of Marketing and Logistics, 19(1), 57-74.

Göksel, A. \& Güneş, G. (2017). Kuşaklar arası farklılaşma: X ve Y kuşaklarının örgütsel sessizlik davranışı bağlamında analizi. Gazi Üniversitesi İktisadi ve İdari Bilimler Fakültesi Dergisi, 19(3), 807-828.

Harrington, M. (2015). Millennials: The "Risk-Averse" Generation? Insights, June 8, https://www.td.org/insights/millennials-the-risk-averse-generation.

Hofstede Insights (2020), https://www.hofstede-insights.com/country-comparison/ turkey, the-usa

Hofstede, G. (2011). Dimensionalizing cultures: The Hofstede model in context. Online Readings in Psychology and Culture, 2(1), 1-26.

Hofstede, G. \& McCrae, R.R. (2004). Personality and culture revisited: Linking traits and dimensions of culture. Cross-cultural Research, 38(1), 52-88.

Hofstede, G., Hofstede, G. J. \& Minkov, M. (2010). Cultures and organizations: Software of the mindm, 3rd Edition. New York: McGraw-Hill.

Homburg, C., Koschate, N. \& Hoyer, W. D. (2006). The role of cognition and affect in the formation of customer satisfaction: A dynamic perspective. Journal of Marketing, 70(3), 21-31.

IMF (2019). Datamapper, World Economic Outlook, October, https://www.imf.org/ external/datamapper/LP@WEO/OEMDC/ADVEC/WEOWORLD.

Issa, T. \& Isaias, P. (2016). Internet factors influencing Generations $\mathrm{Y}$ and $\mathrm{Z}$ in Australia and Portugal: A practical study. Information Processing \& Management, 52(4), 592-617.

Kahraman, M. A. and Dağlı, S. (2019), "Marka algısı, müşteri memnuniyeti ve marka tercihi ilişkisinin X ve Y kuşağına göre incelenmesi”, Uluslararası Ekonomi Isşletme ve Politika Dergisi, 3(2), 381-398.

Khalifa, M. \& Liu, V. (2007). Online consumer retention: Contingent effects of online shopping habit and online shopping experience. European Journal of Information Systems, 16(6), 780-792. 
Khambata, D. \& Liu, W. W. (2005). Cultural dimensions, risk aversion and corporate dividend policy. Journal of Asia-Pacific Business, 6(4), 31-43.

Kim, Y., Sohn, D. \& Choi, S. M. (2011). Cultural differences in motivations for using social network sites: A comparative study of American and Korean college students. Computers in Human , 27(1), 365-372.

Ko, H., Jung, J., Kim, J.Y. \& Shim, S. W. (2004), Cross-cultural differences in perceived risk of online shopping. Journal of Interactive Advertising, 4(2), 2029.

Kocakuş, Z. G. (2019). "Kuşaklar bağlamında marka aşkının marka sadakatine etkisi: Afyonkarahisar'da bir araştırma”, Afyon Kocatepe Üniversitesi Yayınlanmamış Yüksek Lisans Tezi, https://acikerisim.aku.edu.tr/xmlui/ bitstream/handle/11630/7165/10271522.pdf

Korzeniowska, A. (2015). Generation Y on the e-Commerce market: Comparison between Polish and South Korean young consumers'. Journal of Marketing and Consumer Behavior in Emerging Markets, 2(2), 33-48.

Kotler, P. \& Keller, K. L. (2006). Marketing Management, $12^{\text {th }}$ Edition. Upper Saddle River, New Jersey: Pearson Prentice Hall.

Kusek, K. (2016). The death of brand loyalty: Cultural shifts mean it's gone forever. Forbes, July 25, https:/www.forbes.com/sites/kathleenkusek/2016/07/25/thedeath-of-brand-loyalty-cultural-shifts-mean-its-gone-forever.

Lee, Y. H. \& Lim, E. A. C. (2008). What's funny and what's not: The moderating role of cultural orientation in ad humor. Journal of Advertising, 37(2), 71-84.

Lichtenstein, D. R., Netemeyer, R. D. \& Burton, S. (1990). Distinguishing coupon proneness from value consciousness: An acquisition-transaction utility theory perspective. Journal of Marketing, 54(July), 54-67.

Liu, B. S., Furrer, O. \& Sudharshan, D. (2001), "The relationships between culture and al intentions toward services. Journal of Service Research, 4(2), 118-129.

Montana, P. J. \& Petit, F. (2008). Motivating and managing Generation X and Y on the job while preparing for Z: A market oriented approach. Journal of Business \& Economics Research, 6(8), 35-40.

Morgeson III, F. V., Sharma, P. N. \& Hult, G. T. M. (2015). Cross-national differences in consumer satisfaction: Mobile services in emerging and developed markets. Journal of International Marketing, 23(2), 1-24.

Moskowitz, D. (2019). Are millennials risk averse or risk takers? Investopedia, June 25, https://www.investopedia.com/articles/investing/070815/are-millennialsrisk-averse-or-risk-takers.asp. 
Nagy, S. (2017). The impact of country of origin in mobile phone choice of Generation $\mathrm{Y}$ and Z. Journal of Management and Training for Industries, 4(2), 16-28.

Novak, T. P., Hoffman, D. L. \& Yung, Y. (2000). Measuring the customer experience in online environments: A structural modeling approach. Marketing Science, 19(1), 22-42.

Ndubisi, N.O., Malhotra, N.K., Ulas, D. \& Ndubisi, G.C. (2012). Examining uncertainty avoidance, relationship quality, and customer loyalty in two cultures. Journal of International Consumer Marketing, 24(5), 320-337.

Nunnally, J. C. (1978). Psychometric theory. New York: McGraw Hill.

Onurlubaş, E. \& Öztürk, D. (2018). Sosyal medya uygulamalarının Y kuşağı satın alma davranışı üzerine etkisi: Instagram örneği. OPUS International Journal of Society Researches, 9(16), 984-1016.

Optinmonster (2020). Online shopping statistics you need to know in 2020. https:// optinmonster.com/online-shopping-statistics/.

Pappas, I. O., Pateli, A. G., Giannakos, M. N. \& Chrissikopoulos, V. (2014). Moderating effects of online shopping experience on customer satisfaction and repurchase intentions. International Journal of Retail \& Distribution Management, 42(3), 187-204.

Pelet, J. \& Lecat, B. (2014). Smartphones and wine consumers: A study of Gen-Y. International Journal of Wine Business Research, 26(3), 188-207.

Pitta, D. \& Gurău, C. (2012). A life-stage analysis of consumer loyalty profile: Comparing Generation X and Millennial consumers. Journal of Consumer Marketing, 29(2), 103-113.

Pookulangara, S. \& Koesler, K. (2011). Cultural influence on consumers' usage of social networks and its impact on online purchase intentions. Journal of Retailing and Consumer Services, 18, 348-354.

Rajamma, R. K., Pelton, L.E., Hsu, M.K. \& Knight, D.K. (2010). The impact of consumers' need for uniqueness and nationality on Generation Y's retail patronage s: Investigating American and Taiwanese consumers. Journal of Global Marketing, 23(5), 387-410.

Raju, P. S. (1980). Optimum stimulation level: Its relationship to personality, demographics, and exploratory .Journal of Consumer Research, 7(December), 272-282.

Rapp, A., Beitelspacher, L., Grewal, D. \& Hughes, D. (2013). Understanding social media effects across seller, retailer, and consumer interactions. Journal of The Academy of Marketing Science, 41(5), 547-566. 
Reed, C. (2007). Generation Y research: What makes 'Y' tick. Brand Strategy, February 5, 38 .

Rose, S., Clark, M., Samouel, P. \& Hair, N. (2012). Online customer experience in e-retailing: An empirical model of antecedents and outcomes. Journal of Retailing, 88(2), 308-322.

Shobeiri, S., Mazaheri, E. \& Laroche, M. (2018). Creating the right customer experience online: The influence of culture. Journal of Marketing Communications, 24(3), 270-290.

Soares, A. M., Farhangmehr, M. \& Shoham, A. (2007). Hofstede's dimensions of culture in international marketing studies. Journal of Business Research, 60(3), 277-284.

Stafford, T. F., Turan, A. \& Raisinghani, M. S. (2004). International and cross-cultural influences on online shopping. Journal of Global Information Technology Management, 7(2), 70-87.

Statista (2020a). Penetration of leading social networks in Turkey as of 3rd quarter 2019, by platform. https://www.statista.com/statistics/284503/turkey-socialnetwork-penetration/.

Statista (2020b). Most popular mobile social networking apps in the United States as of September 2019, by monthly users. https://www.statista.com/statistics/248074/ most-popular-us-social-networking-apps-ranked-by-audience/.

T.C. Kalkınma Bakanlığı (2018). Kamu bilgi ve iletişim teknolojileri yatırımları. http://www.bilgitoplumu.gov.tr/wp-content/uploads/2018/06/Kamu_BIT Yatirimlari_2018.pdf.

Tyler, K. (2008). Generation gaps. HR Magazine, 53(1), 69-73.

Van der Walt, F., Jonck, P. \& Sobayeni, N. C. (2016). Work ethics of different generational cohorts in South Africa. African Journal of Business Ethics, 10(1), 52-66.

Venkatesh, V., Morris, M. G., Davis, G. B. \& Davis, F. D. (2003). User acceptance of information technology: Toward a unified view. MIS Quarterly, 27(3), 425-478.

Vogels, E. A. (2019). Millennials stand out for their technology use, but older generations also embrace digital life. Pew Research Center, September 9, https:// www.pewresearch.org/fact-tank/2019/09/09/us-generations-technology-use/.

Wang, Y., Wang, Z., Zhang, D. \& Zhang, R. (2019). Discovering cultural differences in online consumer product reviews. Journal of Electronic Commerce Research, 20(3), 169-183.

We Are Social (2020). Digital in 2020. https://wearesocial.com/digital-2020. 
Wiedmer, T. (2015). Generations do differ: Best practices in leading traditionalists, boomers, and Generations X, Y, and Z. The Delta Kappa Gamma Bulletin: International Journal of Professional Educators, 82(1), 51-58.

Yoo, B. (2009). Cross-national invariance of the effect of personal collectivistic orientation on brand loyalty and equity. The United States versus South Korean consumers. Asia Pacific Journal of Marketing and Logistics, 21(1), 41-57.

Zengin, A. Y. \& Kumcu, E. H. (2018). Green Consciousness and Intention To Purchase Green Product: A Comparison Between Generation Y and Z. Conference Paper, IBEMS-International Congress of Business Economics and Marketing, October 11-14, Kiev.

\section{BIOGRAPHICAL SKETCH OF AUTHORS}

Timothy H. Reisenwitz has a DBA in Marketing from Cleveland State University, Cleveland, Ohio, USA, and is Professor of Marketing in the Department of Marketing \& International Business at Valdosta State University, Valdosta, Georgia, USA. His work is published in several journals, including Journal of Consumer Marketing, Marketing Management Journal, Journal of Marketing Education, Marketing Education Review, and Journal of Business Strategies. Timothy H. Reisenwitz is the corresponding author and can be contacted at treisenw@valdosta.edu.

Ilke Kardes is currently an Assistant Professor of Marketing \& International Business at Valdosta State University. Previously, Dr. Kardes taught classes in International Business and served as Research Director at the Center for International Business and Education Research (CIBER) at Georgia State University. Her academic career and abilities have been shaped in different cultures including United States, Germany, and Turkey during years. Ilke is fluent in English, German, and Turkish.

Asude Yasemin Zengin is an Assistant Professor in the Health Management Department at Aksaray University's School of Health Sciences. She has publications on international marketing, social media marketing and consumer behavior also, has authored books on the export performance of emerging markets and integrated marketing communications. Dr. Zengin earned her master's degree and doctorate from Gazi University. She worked as a visiting scholar at Georgia State University Center for International Business in the 2011-2012 academic calendar. 